\title{
The Effect of a Psychomotor Program on the Degree of Self-Concept of the Mentally Handicapped
}

\section{"Dr/ Al-Zahra Rashad Muhammad}

\section{Introduction:}

With the increase in the number of the disabled in the world significantly and significantly, especially in recent times, and after the spread of health factors that afflict the pregnant mother before and during childbirth and that cause disability, great interest has emerged in the categories of the disabled at all levels, as the proportion of the disabled in the world today has increased to the equivalent of $13.5 \%$ of the total The world population with the beginning of the twenty-first century, and according to the estimates of the Central Agency for Public Mobilization and Statistics, it becomes clear that the estimated percentages of the mentally handicapped in Egypt for the year (2015) amounted to $(131,637.4)$ children, and the mental (intellectual) disability represents the center of gravity in the types of disabilities, where the rate of retardation reaches Simple mental to $2.5 \%$ and severe $0.5 \%$ by $3 \%$ of the total population in the age of 6-16 years and up to $4 \%$ of the total number of children in Egypt, as reported in the UNICEF study (44) (45) (46). International and human rights organizations, provided that the disabled take their share of care, attention, rights and duties.

Disability is considered one of the important problems that require more attention to confront it and work to find appropriate solutions for it in a scientific way so that it does not become an obstacle to the progress of society. (37: 7) (43)

Disability results in psychological effects that may cause major changes in the personality of the individual, for the individual collects all his internal and external experiences in light of his perception of his physical self, and most people plan for their lives based on their understanding of their physical self and any disability that threatens the person in his present and future and leads to disruption of his human capabilities and thus raises his fears And his anxiety, many psychological effects may occur, such as an excessive feeling of inferiority, powerlessness, insecurity, and excessive defense. (1:46) (149:2) (7: 9) (41:12)

The problem of mental disability is one of the unique problems that cannot be similar to another of the problems of disability because it is multidimensional and its dimensions are medical, social, psychological and professional, which makes it a unique problem, and its difficulty lies in the possibility of its occurrence from birth to the first eighteen years of life and its effects appear. In the academic, social, professional and other fields of life. $(13: 11)(19: 62)(647: 33)$

\section{"Assistant Professor, Department of Sports Psychology Faculty of Physical Education - Minia University.}


And since sports practice is thanks to the situations it allows for interaction with oneself and with the group, the civilized nations have paid attention to sports recreational activities for the normal and the handicapped alike in order to benefit from them in the advancement of the individual physically, mentally and spiritually and to awaken and revitalize social awareness, especially the activities practiced by the disabled, which make them feel the need for the group And the value of cooperating with it, as we make them accustomed to abiding by the laws and obeying them, and thus interacting with the group. (184: 13)

If sports recreational activities represent an important and useful aspect in developing many aspects of the normal, then it is an inevitable necessity for the mentally handicapped because it has an attractive and favorable effect on their souls. Many Arab and foreign references indicate that mentally handicapped children suffer from many psychological problems and they have many The needs of a greater proportion of normal children, as behavioral problems arise from the difference between the child's abilities to achieve and the requirements of the environment in which he lives, and it is necessary for there to be a compatibility between the child's environment and his school and his ability to learn and achieve, as the amount of stimuli that the child is exposed to is The basis for shaping his personality and behavior. (13: 222) (28:45) (47: 178)

The philosophy behind physical activity and its usefulness for this group lies in providing suitable opportunities for them to participate in recreational sports activities and various group games, which contributes to positively changing their self-image as well as increasing their integration as their normal counterparts alike, so the researcher chose to design the use of recreational games. To know its impact on the self-concept of the mentally handicapped. (48: 354-358)

\section{Research goal:}

The research aims to identify the effect of a psychomotor program on the degree of self-concept of mentally handicapped people through: -

1- The significance of the differences between the pre and post measurements of the experimental group in the concept of self among the mentally handicapped.

2- The significance of the differences between the control and experimental groups in the self-concept of the mentally handicapped.

Research hypotheses :

1- There are statistically significant differences between the pre and post measurements of the experimental group in the self-concept of the mentally handicapped in favor of the post measurement.

2- There are statistically significant differences between the two experimental control groups in the self-

Assiut Journal For Sport Science Arts 
concept of the mentally handicapped in favor of the experimental group.

Scientific terms used in the research: Self-concept:

It is the individual's perception of his adequacy in social, cognitive and physical situations. (14:8) (40:26)

\section{Handicapped:}

It is every individual who differs from who is called a word other than or ordinary, physically, mentally, psychologically, or socially to the extent that it inspires special rehabilitation processes in order to achieve the maximum adaptation that his remaining abilities or capabilities allow. (37:26)

\section{Search procedures: -}

\section{Research Methodology:}

The researcher used the experimental method by designing two groups, one experimental and the other controlling for its relevance and the nature of this study.

The research sample:

The study was carried out on (28) children who are mentally handicapped (who are able to learn) and whose IQ ranges from (50-70 degrees) and their mental age ranges from (8-10) years, and the chronological age is between (15-18) years, in Minya School of Intellectual , And they were divided into (8) children for an exploratory study, (20) children for the basic study by (10) children for each of the experimental group and the control group, and the following took into account when choosing the sample:

They do not have any movement disabilities or physical illnesses, nor do they have minor or major seizures.

- All members of the sample are male, in order to ensure that sexual problems between boys and girls are avoided.

Sample homogeneity:

The homogeneity was conducted among the sample members by finding the torsion factors in age, height, weight and IQ on 9/20/2019, which is shown in Table (1).

Table (1)

The arithmetic mean, standard deviation, and torsion coefficient value of the research sample in age, mental age, height, weight, and IQ $(n=20)$

\begin{tabular}{l|c|c|c}
\hline \hline Variables & SMA & standard deviation & Coefficient of torsion \\
\hline \hline Age & 12.89 & 1.52 & 1.86 \\
\hline Mental age & 5.14 & 1.37 & 1.28 \\
\hline Height & 146.94 & 1.21 & 0.81 \\
\hline Weight & 62.78 & 1.61 & 1.68 \\
\hline IQ & 61.08 & 7,11 & 1,48 \\
\hline \hline
\end{tabular}

It is evident from Table (1) that the values of the torsion coefficients of the research sample in the variables of age, height, weight and IQ ranged between $(0.81$ - 1.86) and that they were confined to $(+3,-3)$, indicating the moderation of the distribution of

Equivalence of the sample:

The equivalence of the two groups of research in the variables (under investigation) was found using Wilcoxon's coefficient, on 7/10/2019, and Table (2) shows that: the research sample in these variables. 
Table (2)

The arithmetic mean, standard deviation, and $(Z)$ value between the experimental and control groups in pre-measurement in age, mental age, height, weight, IQ and self-concept $(\mathrm{N}=20)$

\begin{tabular}{l|c|c|c|c|c}
\hline \multirow{2}{*}{ Dimensions } & \multicolumn{2}{|c|}{ Experimental } & \multicolumn{2}{c|}{ Control } & \multirow{2}{*}{$\begin{array}{c}\text { Value (Z) } \\
\text { Calculated }\end{array}$} \\
\cline { 2 - 5 } & $\mathrm{S}$ & $\mathrm{E}$ & $\mathrm{S}$ & $\mathrm{E}$ & 0.024 \\
\hline \hline Age & 16.78 & 1.43 & 16.94 & 1.64 & 0.031 \\
\hline Mental age & 9.10 & 1.32 & 9.18 & 1.41 & 0.014 \\
\hline Height & 157.05 & 1.24 & 156.85 & 1.11 & 0.016 \\
\hline Weight & 72.72 & 1.58 & 72.83 & 1.62 & 0.023 \\
\hline IQ & 61.17 & 7,06 & 60.98 & 7,16 & \\
\hline Self concept & & & & & 0.026 \\
\hline Realistic self & 113.17 & 1.19 & 114.24 & 1.84 & 0.011 \\
\hline Self-acceptance & 86.55 & 1.56 & 85.24 & 1.92 & 0.020 \\
\hline Perceptual self & 99.14 & 1.64 & 100.04 & 1.77 & 0.018 \\
\hline The physical self & 65.18 & 1.53 & 66.38 & 1.34 & 0.021 \\
\hline The moral self & 64.91 & 1.82 & 65.72 & 1.65 & 0.031 \\
\hline The personal self & 54.18 & 1.19 & 55.12 & 1.12 & 0.019 \\
\hline The family self & 61.87 & 1.53 & 62.43 & 1.86 & 0.010 \\
\hline The social self & 60.04 & 1.82 & 60.58 & 1.54 & 0.015 \\
\hline Self-criticism & 30.88 & 1.09 & 31.02 & 1.22 & \\
\hline \hline
\end{tabular}

(Z) tabular value $=0.042$

It is evident from Table (2) that there are no statistically significant differences between the experimental and control groups in age, mental age, height, weight, IQ and self-concept, which indicates the equivalence of the two research groups.

Data collection tools:

Self-concept scale (to forget): Attachment (1)

The researcher used the Tennessee Self - Concept Scale after presenting it to psychology experts (attached 3) to express an opinion on its suitability for the sample under study. $80 \%$ of them agreed on its suitability for the sample under study.

\section{Program goal:}

- Work to ensure that the mentally handicapped acquire physical fitness.

- Providing the mentally handicapped person with a wide variety of skills.

- Work to develop a positive selfconcept in this category.

General principles for developing the program:

Comprehensive development:

A set of exercises and small games aimed at developing body parts and thus performance includes moving different parts of the body through the program, as well as developing some different physical characteristics such as strength, flexibility, compatibility

Assiut Journal For Sport Science Arts 
and accuracy due to its great importance for the mentally handicapped individual.

Taking into account the intellectual disability of the children in question:

When developing the proposed program of mini-games, the researcher took into account that it be in line with the percentage of intellectual disability and take into account that the contents of the program suit the abilities of children, as it is characterized by simplicity, ease, and the possibility of performance for all.

- Clear explanation: the researcher sponsored to explain the contents of the program using simple and clear words appropriate to the degree of intellectual disability and the level of abilities in order to be properly understood.

- That the individuals have security and safety factors.

- Taking into account the continuity of the implementation of the program.

Table (3)

Percentage of expert opinion on the time distribution of the proposed program $(\mathbf{n}=\mathbf{1 0})$

\begin{tabular}{c|l|c|c}
\hline \multicolumn{3}{c}{$(\mathbf{n = 1 0})$} \\
\hline \hline $\mathbf{S}$ & Axis & $\begin{array}{c}\text { Expert opinion in } \\
\text { agreement }\end{array}$ & $\%$ \\
\hline \hline 1 & Program Duration (10 weeks) & 9 & $90 \%$ \\
\hline 2 & Number of units (two units per week) & 10 & $100 \%$ \\
\hline 3 & Unit time (45 minutes) & 10 & $100 \%$ \\
\hline 4 & $\begin{array}{l}\text { Time for the introductory part and } \\
\text { introduction (15 minutes) }\end{array}$ & 8 & $80 \%$ \\
\hline 5 & Core segment time (25 minutes) & 9 & $90 \%$ \\
\hline 6 & $\begin{array}{l}\text { Closing and Cooling Down Time (5 } \\
\text { minutes) }\end{array}$ & 9 & $90 \%$ \\
\hline \hline
\end{tabular}

Assiut Journal For Sport Science Arts
- That the content of the units work to feel pleasure and happiness and get rid of boredom and tension.

- Taking into account the change and diversity in the paragraphs of the program activities.

Principles of developing the program:

In preparing the program, it was taken into account that it includes various types of recreational minigames that contribute to the development of the muscular aspect as well as the development of a positive self-concept among the mentally handicapped through the practice of sporting recreational activity. The amendment was made in light of the opinions and suggestions of the experts, and thus the program became valid for implementation. The following table shows the percentage of experts' approval of the proposed program attempt: - 
It is clear from Table (5) that the percentage of experts 'opinions about the time distribution of the program ranged between $(80 \%-100 \%)$, and the researcher agreed to accept a rate of $70 \%$ or more, based on previous studies.

Presentation and discussion of results:

Table (4)

The arithmetic mean, standard deviation, improvement percentage, and $(Z)$ value between the pre and post measurements of the experimental group of selfconcept $(n=20)$

\begin{tabular}{|c|c|c|c|c|c|c|}
\hline \multirow{2}{*}{$\begin{array}{l}\text { Dimensions of } \\
\text { the Self-Concept } \\
\text { Scale }\end{array}$} & \multicolumn{2}{|c|}{ Pre measure } & \multicolumn{2}{|c|}{ Post measure } & \multirow{2}{*}{$\begin{array}{l}\text { Improvement } \\
\text { percentage }\end{array}$} & \multirow{2}{*}{$\begin{array}{c}\text { The } \\
\text { computed } \\
(\mathrm{Z}) \text { value } \\
\end{array}$} \\
\hline & $\mathbf{S}$ & $\mathbf{E}$ & $\mathbf{S}$ & $\mathbf{E}$ & & \\
\hline Realistic self & 113.17 & 1.19 & 137.33 & 1.81 & $21.35 \%$ & 0.052 \\
\hline Self-acceptance & 86.55 & 1.56 & 113.82 & 1.88 & $31.51 \%$ & 0.063 \\
\hline Perceptual self & 99.14 & 1.64 & 124.84 & 1.76 & $25.92 \%$ & 0.059 \\
\hline The physical self & 65.18 & 1.53 & 94.56 & 1.32 & $45.08 \%$ & 0.089 \\
\hline The moral self & 64.91 & 1.82 & 89.14 & 1.64 & $37.33 \%$ & 0.069 \\
\hline The personal self & 54.12 & 1.19 & 75.78 & 1.11 & $40.02 \%$ & 0.077 \\
\hline Familial & 61.87 & 1.53 & 88.56 & 1.85 & $43.14 \%$ & 0.083 \\
\hline The social self & 60.04 & 1.82 & 83.17 & 1.55 & $38.53 \%$ & 0.072 \\
\hline Self-criticism & 30.88 & 1.09 & 42.82 & 1.21 & $39.05 \%$ & 0.074 \\
\hline
\end{tabular}

(Z) tabular value $=0.042$

Table (4) shows that there are statistically significant differences between the pre and post

Table (5)

measurements of the experimental group in favor of the post measurement in all dimensions of the self-concept.

The arithmetic mean, standard deviation, percentage improvement, and $(Z)$ value between the two experimental groups The dimensional control in selfconcept $(n=20)$

\begin{tabular}{l|c|c|c|c|c|c}
\hline \hline $\begin{array}{c}\text { Dimensions of } \\
\text { the Self- } \\
\text { Concept Scale }\end{array}$ & \multicolumn{2}{|c|}{ Experimental } & \multicolumn{2}{|c|}{ Control } & $\begin{array}{c}\text { Improvement } \\
\text { percentage }\end{array}$ & $\begin{array}{c}\text { The computed } \\
\text { (Z) value }\end{array}$ \\
\cline { 2 - 7 } & $\mathbf{S}$ & $\mathbf{E}$ & & & & \\
\hline \hline Realistic self & 137.33 & 1.81 & 118.33 & 1.92 & $16.06 \%$ & 0.044 \\
\hline Self-acceptance & 113.82 & 1.88 & 91.81 & 1.61 & $23.97 \%$ & 0.057 \\
\hline Perceptual self & 124.84 & 1.76 & 104.67 & 1.53 & $19.27 \%$ & 0.050 \\
\hline $\begin{array}{l}\text { The physical } \\
\text { self }\end{array}$ & 94.56 & 1.32 & 71.49 & 1.48 & $32.27 \%$ & 0.063 \\
\hline \hline
\end{tabular}

Assiut Journal For Sport Science Arts 
Follow Table (5)

The arithmetic mean, standard deviation, percentage improvement, and $(Z)$ value between the two experimental groups The dimensional control in selfconcept $(n=20)$

\begin{tabular}{|c|c|c|c|c|c|c|}
\hline \multirow{2}{*}{$\begin{array}{c}\text { Dimensions of } \\
\text { the Self- } \\
\text { Concept Scale }\end{array}$} & \multicolumn{2}{|c|}{ Experimental } & \multicolumn{2}{|c|}{ Control } & \multirow{2}{*}{$\begin{array}{c}\text { Improvement } \\
\text { percentage }\end{array}$} & \multirow{2}{*}{$\begin{array}{l}\text { The computed } \\
\text { (Z) value }\end{array}$} \\
\hline & $\bar{S}$ & $\overline{\mathbf{E}}$ & & & & \\
\hline The moral self & 89.14 & $\overline{1.64}$ & 71.09 & $\overline{1.84}$ & $25.39 \%$ & 0.058 \\
\hline $\begin{array}{l}\text { The personal } \\
\text { self }\end{array}$ & 75.78 & 1.11 & 61.58 & 1.37 & $23.06 \%$ & 0.055 \\
\hline Familial & 88.56 & 1.85 & 70.37 & 1.94 & $25.85 \%$ & 0.059 \\
\hline The social self & 83.17 & 1.55 & 67.21 & 1.75 & $23.75 \%$ & 0.056 \\
\hline Self-criticism & 42.82 & 1.21 & 35.51 & 1.39 & $20.59 \%$ & 0.051 \\
\hline
\end{tabular}

(Z) tabular value $=0.042$

It is evident from Table (5) that there are statistically significant differences in the measurement and dimension of the experimental and control groups in favor of the post measurement of the experimental group in all dimensions of the selfconcept.

It is evident from tables (4) and (5) that there are statistically significant differences between the pre and post measurements in all dimensions of the self-concept, and the researcher attributes these statistically significant differences between the pre and post measurements of the experimental group and in favor of the post to the practice of sports recreational activities, especially for the mentally handicapped group, which helps To increase the psychological balance of the individual, which is determined on the basis of the extent of integration between the energies of the body and the mind and his abilities to carry out the duties surrounded by him by society and his abilities to adapt, produce and achieve self and establish social relations that enable him to meet the demands of life and that helps him to feel contentment and pleasure and the means that achieve a better level From the psychological health and emotional balance of the mentally handicapped, and this is what the study confirmed that the practice of recreational games is an important factor affecting self-concept and also the study of "Nermin Ahmed AbdelSabour" 2007 AD (31) on the effect of the recreational program on the degree of personal and social compatibility among the handicapped, which resulted in the results that The proposed program increases the percentage of improvement for the experimental group in personal and social compatibility, as is evident as well That the dimension of the real self-came in the first order, followed by the perceptual self in the second order, then the self-acceptance in the third order. This means that the proposed recreational program has a positive effect on the degree of the real self, through the practice of sporting

Assiut Journal For Sport Science Arts 
recreational activities that provide the individual with a sense of happiness and freedom from psychological tension and so on. These activities have positive effects on the physical, psychological and moral aspects of the disabled, as they gain many psychological and social values such as leadership, dependency and selfconfidence, as well as the fun and challenge that it represents in competition in winning and excelling (12: 284) (24: 95) (40: 76- 79)

The results of this study also agree with Magda El-Sayed Mahmoud (2000 AD) (20), who confirmed that practicing buds activity as an educational promotional stimulant has a positive effect on some aspects of growth and behavior for both the level of motor, social, moral and cognitive development of pre-school children from the age of (4-) 6 years) and the results of this study also agree with the results of Adel Saad Khalil (1992) (10) study, which indicates the importance of the counseling program in play and the effectiveness of using play in modifying behavioral problems, and these results are also consistent with the results of the study of Muhammad Mahmoud Abu Zaid (2004 AD) (25) Malik Ahmed Abdel Aziz (1993) (29) on the importance of the kinematic story and the group play program in improving the level of motor fitness, developing innovative thinking and reducing behavior. These results are consistent with the results of the study of Azza Abdel Fattah Lashimi (1995 AD) (14) until The mini-games program has a positive effect on some elements of physical fitness, as it is suitable for the mentally handicapped category and helps to learn motor skills, in addition to it gaining the disabled many skills that enable him to enjoy his spare time and increase his motor abilities that are an essential aspect of self-concept. This result is consistent with the study of Amal Mahrous (2002) (4) and Nermin Abdel Sabour (2007) (31) on the importance of practicing sports activities and its role in the integrated development of the mentally handicapped person, and the researcher believes that by encouraging and constantly motivating children and urging them to perform and encourage any improvement Even if it was slight, as well as the gradual transition during the implementation of the program and making every child boast of his success, as it was possible to rely on them to bring tools and return them, and they became daring to speak without fear or shame, and a constant desire to win. (25: 164-171)

\section{Conclusions:}

In light of discussing the results, the researcher reached the following conclusions: -

1- The psychomotor games program has a positive effect on developing the self-concept of the mentally handicapped.

2- There are statistically significant differences between the pre and post measurements of the experimental group in the development of selfconcept and in favor of the post measurement.

3- There are statistically significant differences between the experimental and control groups in postmeasurement in developing self- 
concept and in favor of the experimental group.

4- Children who belong to socially average environments and whom the family depends on in the conduct of their lives and giving them the opportunity to deal with simple cash in buying and selling increases their social intelligence and dependence on themselves.

\section{Recommendations:}

Through the conclusions that could be reached, and within the limits of the research sample, the researcher recommends the following: -

1- Application of the proposed recreational program on the different categories of mental disability because of its positive impact on the development of their self-concept.

2- The use of psychomotor games in developing the self-concept of the mentally handicapped.

3- Using psychomotor games with other disabilities.

4- Using psychomotor games with mentally handicapped children in different age groups.

5- The application of the proposed psychomotor games within the various centers for the disabled and intellectual schools because of its importance in developing the self-concept of the mentally handicapped.

7 - Supporting the positive self-concept of mentally handicapped people by stimulating their motivation to participate in recreational programs.

8- Providing qualified leaders to work on developing positive self-concept among mentally handicapped people.

9- Conducting more scientific research to study the relationship between self- concept and aspects of sports activity for the mentally handicapped.

10. Directing the guardian of the mentally handicapped child to provide the opportunity to increase the child's social contact in the home and the surrounding community and to increase his dependence on himself to develop his social skills.

\section{References}

1- Abdel Azim Shehata: Vocational Rehabilitation and the Mentally Retarded, The Egyptian Renaissance Library, Cairo 1991 AD.

2- Abdel Hay Mahmoud Hassan: Challenging Disabilities from the Perspective of Social Service, Dar Al Ma'arif, University Knowledge, Alexandria 1999 AD.

3- Adel Saad Khalil: A comparative study of some customary and social characteristics of mentally retarded children from the category of mental retardation and non-retarded children. Unpublished $\mathrm{PhD}$ thesis, Institute of Higher Studies for Childhood, Ain Shams University 1992 AD.

4- Ahmed Muhammad Al-Akkad: The Impact of Small Games and the Kinetic Story on Perceptual Kinetic Abilities and the Level of Skill Performance in Football for Deaf and Dumb Students, Journal of Physical Education Research, Faculty of Physical Education, Boys, Zagazig University, Volume 25, Issue 60, Part Two, August 2002 AD.

5- Ahmed Zaki Saleh: Educational Psychology, 3rd Edition, Cairo, The Egyptian Renaissance Library, 1988 AD.

6- Amin Anwar Al-Khouly, Osama Kamel Ratib, Muhammad Hassan 
Allawi: Kinetic Education of the Child, 5th Edition, Arab Thought House, Cairo 1998 AD.

7- Amal Muhammad Mahrous: A proposed program to teach basic swimming skills to mentally handicapped children and its impact on some psychological and social aspects, an unpublished master's thesis, College of Physical Education for Girls, Alexandria University, 2002.

8- Ayat Yahya Abd al-Hamid Abd al-Rahim: The Impact of a Proposed Program for Kinetic Education on the Kinetic, Psychological and Social Efficiency of Mentally Handicapped, Unpublished Master Thesis, College of Physical Education for Girls, Helwan University, 2003

9- Azza Abd Al-Fattah Al-Shimi: The effect of a proposed program for small games on the performance of some offensive skills in basketball for the mentally retarded, a scientific journal specialized in physical education sciences, Faculty of Physical Education for Boys, Issue (24), Alexandria 1995 AD.

10- Azza Khalil Abdel Fattah: The Psychology of Play in Early Childhood, Arab Thought House, Cairo 2002.

11- Christine Miles: The mentally handicapped child and how to deal with it, translated by Laila Abu Shaar, review by Hussein Salah El-Din, 2nd ed., Al-Mahabba Association Publications, Damascus 1992 AD.

\section{2- Congratulations Hassan} Abdullah: A proposed program for teaching mathematics to mentally handicapped students in schools of intellectual education, unpublished
$\mathrm{PhD}$ thesis, South Valley University in Qena 1992.

13-Helmy Ibrahim, Leila Farhat: Physical Education and Recreation for the Disabled, Cairo, Arab Thought House, 1988 AD.

14-Ibrahim Abbas Al-Zuhairy Amin: The Philosophy of Education for People with Special Needs and Their Education Systems Zahra AlSharq Library, 2003 AD.

15- Laila Karam El-Din: Recent trends in caring for the disabled, published research, Child Cultural Series, Child Studies Center, Ain Shams University, 1994 AD.

16- Magda El-Sayed Mahmoud: The effect of a movement program using some innovative tools on the motor performance and personal and social adaptation of mentally handicapped students, an unpublished master's thesis, Faculty of Physical Education for Girls, Alexandria University, 2000 AD.

17- Mahmoud Abdel-Fattah Anan: Caring for the Disabled Child, Safir Educational Series, Cairo, 1999.

18- Mahmoud Abdel-Fattah Anan, Anan Darwish: Sports and Recreation for the Disabled, Medina, Arab Renaissance Library, 1990 AD.

19- Malak Ahmed Abdel Aziz: The Effectiveness of the Inclusion System in Improving Some Aspects of the Consensual Behavior of Mentally Retarded Pupils who are Able to Learn, Unpublished Master Thesis, Faculty of Education, Ain Shams University 1993 AD.

20- Muhammad Al-Sayed Halawa: Mental Retardation in the Family 
Circumference, Scientific Bureau for Publishing and Distribution, Alexandria 1998 AD.

\section{1- Muhammad Mahmoud Abu} Zaid: The effectiveness of a proposed program for small games in improving compatibility with life for the mentally handicapped, an unpublished master's thesis, College of Physical Education for Girls, Alexandria University, 2004 AD.

22- Muhammad Naguib Tawfiq: Social Service with Special Groups, Faculty of Social Work, Cairo, Helwan University, 1988 AD.

23- Muhammad Shaheen: Understanding the psychological problems of the handicapped as a means to reduce disability, Cairo, the Fourth Conference of the Handicapped Union, December, 1988 AD.

24- Muhammad Sobhi Hassanein: Evaluation and Measurement in Physical Education, Part One, Arab Thought House, Cairo.

25- Nermin Ahmed Abdel-Sabour: The behavior of a sports coach and its effect on psychological problems and the athletic level of the mentally handicapped, the message of the sports path and its impact on the psychological problems and sports level of the mentally handicapped, an unpublished $\mathrm{PhD}$ thesis, Faculty of Physical Education for Girls, Alexandria University, 2007 AD.

26- Nibras Yunus Muhammad Al Murad: The Effect of Using a Program for Kinetic, Group and Mixed Games on the Development of Social Interaction among Riyadh Children (56) Years Old, Unpublished Master Thesis, College of Education (2004 AD).

27- Kamal Darwish, Amin ElKhouly: Fundamentals of Recreation and Recreation, Introduction to Human Sciences, House of Arab Thought Library, Cairo, 1990.

28- Kamal Ibrahim Moussa: References in the science of mental retardation, Egyptian Universities Publishing House, Cairo 1996.

29- Safwat Farag: Mental Retardation (Current Status and Future Prospects), Psychological Studies, July, The Anglo-Egyptian Press, Cairo 1992 AD. 